\title{
Approaches to describing and analyzing classroom communication
}

\begin{abstract}
The article discusses some selected approaches to classroom communication and addresses the problem of its authenticity. The complexity of the subject, together with the multiplicity of the models, interpretations and research methodologies used in the process of data collection and analysis contribute to the fact that classroom discourse is generally regarded as a problematic and demanding research area which requires a multi-dimensional approach and a well-grounded choice of analytic framework.
\end{abstract}

KEYWORDS: classroom communication, discourse, interaction, authenticity, interaction analysis, discourse analysis, conversation analysis.

\section{INTRODUCTION}

Classroom communication has been the object of particular research interest since the 1960s. Researchers have attempted to identify typical classroom speech events and participation structures, examine the character of teacher talk, indicate the effects of different types of communicative patterns used in the language classroom on learning and investigate the influence of cultural factors on the nature of classroom interaction. In fact, the variety of elements which create the shape of such communication, together with several methodological and technical problems involved in the process of data collection and analysis, result in a tendency to treat classroom discourse as a rather problematic medium which is not likely to submit to simple, predictable or unanimous interpretations.

Different approaches to pedagogic discourse stem, to a great extent, from employing differing research traditions to classroom discourse analysis. Since they follow various types of research design and attempt to implement diverse goals, the task of defining common ground for their evaluation 
seems, as Majer (2003: 36) points out, very difficult, if not impossible. The table below presents the major research areas that have been investigated within mainstream approaches:

Table 1. Approaches to classroom discourse analysis - compiled on the basis of Majer (2003:36-58)

\begin{tabular}{|c|c|c|}
\hline Approach & Research areas & Representatives \\
\hline 1 & 2 & 3 \\
\hline $\begin{array}{l}\text { The sociolinguistic } \\
\text { approach }\end{array}$ & $\begin{array}{l}\text { - key question: determining whether pedagogic discourse is } \\
\text { a specific discourse style in its own right, } \\
\text { - analyzing patterns of interaction in instructional envi- } \\
\text { ronments (content-area teaching in L1), } \\
\text { - examining linguistic variables of L1 classroom discourse } \\
\text { in relation to learning, } \\
\text { - identifying the hierarchical structure and the institutionalized } \\
\text { roles of participants of educational discourse, } \\
\text { - differences between pedagogic and naturalistic discourse, } \\
\text { - application of postulated analytical systems for foreign } \\
\text { language classrooms, } \\
\text { - investigating triadic IRF exchange, turn-taking systems } \\
\text { and teacher talk. }\end{array}$ & $\begin{array}{l}\text { Bellack et al. (1966); } \\
\text { Bernstein (1990); } \\
\text { Mehan (1979); } \\
\text { Sinclair, Coulthard } \\
\text { (1975). }\end{array}$ \\
\hline $\begin{array}{l}\text { The structural } \\
\text { approach }\end{array}$ & $\begin{array}{l}\text { - linking psychology with pedagogy, } \\
\text { - analyzing individual utterances, particularly the ways in } \\
\text { which they form larger units of discourse, } \\
\text { - categorizing contributions to classroom talk, } \\
\text { - compiling the systems of coding classroom talk, } \\
\text { - defining patterns of participation in language classroom, } \\
\text { - the treatment of learners' errors, } \\
\text { - identifying types of language learners, } \\
\text { - analyzing sociolinguistic patterns of classroom discourse, } \\
\text { - use of observation schemes and quantitative methods in } \\
\text { examining different aspects of classroom interaction. }\end{array}$ & $\begin{array}{l}\text { Amidon, Hough } \\
(1967) ; \\
\text { Barnes et al. (1969); } \\
\text { Flanders (1970); } \\
\text { Moskowitz (1971); } \\
\text { Politzer (1980); } \\
\text { Seliger (1977). }\end{array}$ \\
\hline $\begin{array}{l}\text { The psycholinguistic } \\
\text { approach }\end{array}$ & $\begin{array}{l}\text { - dependency between the discourse used in formal instruc- } \\
\text { tional environments and its effects on learning, } \\
\text { - roles of modified input and negotiated interaction in } \\
\text { instructed second language acquisition. }\end{array}$ & $\begin{array}{l}\text { Chaudron (1988); } \\
\text { Ellis (1994; 1999); } \\
\text { Hatch (1992); } \\
\text { Larsen-Freeman (1998); } \\
\text { Riley (1985). }\end{array}$ \\
\hline $\begin{array}{l}\text { The interactionist } \\
\text { approach }\end{array}$ & $\begin{array}{l}\text { - foreigner talk discourse - focus on adjustments in the } \\
\text { input of adult native speakers addressed to less proficient } \\
\text { adult non-native speakers, } \\
\text { - comparing foreigner talk with classroom interactive dis- } \\
\text { course, } \\
\text { - studies in teacher talk analyzing input to the learner and } \\
\text { an occupational register of pedagogic discourse, } \\
\text { - teacher questioning styles, } \\
\text { - patterns of teacher-learner participation in classroom } \\
\text { interaction, } \\
\text { - teacher feedback and error correction styles, } \\
\text { - social interaction and negotiation of meaning in exchanges } \\
\text { between learners and native-speaker interlocutors. }\end{array}$ & $\begin{array}{l}\text { Long, Richards (1987); } \\
\text { Pica (1987; 1994). }\end{array}$ \\
\hline
\end{tabular}


tab. 1

\begin{tabular}{|c|c|c|}
\hline 1 & 2 & 3 \\
\hline $\begin{array}{l}\text { The strategic } \\
\text { approach }\end{array}$ & $\begin{array}{l}\text { - ways of outperforming a learner's competence in dealing } \\
\text { with communicative problems, } \\
\text { - studies in communication strategies and their effects on } \\
\text { interaction in instructional and non-instructional settings, } \\
\text { - taxonomies of learner communication strategies, } \\
\text { - teacher-talk strategies. }\end{array}$ & $\begin{array}{l}\text { Niżegorodcew (1991; } \\
\text { 1993); } \\
\text { Patil (1994); } \\
\text { Yule, Tarone (1997). }\end{array}$ \\
\hline $\begin{array}{l}\text { The methodological } \\
\text { approach } \\
\text { (corresponding to } \\
\text { pre-service teacher } \\
\text { training) }\end{array}$ & $\begin{array}{l}\text { - patterns of classroom participation, } \\
\text { - teachers' questioning styles, } \\
\text { - qualitative and quantitative aspects of teacher talk, } \\
\text { - feedback, } \\
\text { - the role of the first language in foreign language class- } \\
\text { room communication, } \\
\text { - classroom management discourse, } \\
\text { - classroom observation. }\end{array}$ & $\begin{array}{l}\text { Allwright (1988); } \\
\text { Cullen (1998); } \\
\text { Lynch (1996); } \\
\text { Majer (1998); } \\
\text { Nunan (1989); } \\
\text { Nunn (1999); } \\
\text { Thompson (1997). }\end{array}$ \\
\hline $\begin{array}{l}\text { The reflective } \\
\text { approach } \\
\text { (corresponding to } \\
\text { in-service teacher } \\
\text { training and teacher } \\
\text { development) }\end{array}$ & $\begin{array}{l}\text { - action research aimed at improving practice and under- } \\
\text { standing of the teaching/learning process, } \\
\text { - classroom research - collaborative initiatives aimed at } \\
\text { testing theories, } \\
\text { - investigations into teaching styles and methodologies of } \\
\text { language teacher education in various institutional and } \\
\text { cultural contexts. }\end{array}$ & $\begin{array}{l}\text { Cullen (1998); } \\
\text { Majer (1998); } \\
\text { Nunan (1989); } \\
\text { Richards, Lockhart } \\
\text { (1994); } \\
\text { Wallace (1998). }\end{array}$ \\
\hline
\end{tabular}

In fact, early sociolinguistic research, based on first-language educational discourse analyses, resulted in descriptions of classroom communication with all its distinctive features which took into account the differences between a casual conversation and pedagogic discourse (Majer 2009: 100). One of the outcomes of such an approach, which defined classroom interaction as a specific example of institutional (or, using a negative stereotype, artificial) discourse, existing and well-grounded only within a restricted context of educational settings, was the initiation of a worldwide discussion on the character and authenticity of classroom communication (as opposed to natural or naturalistic discourse) that has been ongoing since then among researchers of different methodological backgrounds. Thus, the models of classroom discourse that have emerged so far draw on different theoretical traditions, various ethnographic and psychological approaches, or they are eclectic in their methodological frameworks. Due to the scope of the research in the area, the present article offers only a brief selection of the views which seem most relevant to the context of general discussion and seem to best serve the purpose of indicating the prevailing directions and perspectives in classroom discourse investigation. 


\section{CLASSROOM COMMUNICATION - MODELS AND INTERPRETATIONS}

It has to be underlined that the context of foreign language teaching and learning requires a specific approach to classroom discourse as the target language functions here as both the medium and the goal of teaching (Majer 2003: 9). The views on classroom communication presented below are thus situated within the area of foreign language pedagogy although they reflect different theoretical orientations and are aimed at implementing various pedagogic or research goals. Yet, in spite of numerous differences in their conceptual and methodological frameworks, they acknowledge the importance of the character of the relationship between the teacher and learners in the classroom, and its impact on the maintained communicative patterns. Additionally, they seem to share a view that educational discourse constitutes a specific discourse style, authentic within its own context, and they recognize the potential flexibility and dynamic nature of classroom interaction.

Johnson (1995) proposes an integrated view of communication in second language classrooms and puts forward a framework which may be used for describing and analyzing classroom interaction. She identifies the most essential aspects of classroom discourse: the academic task structures, the social participation structures and the ways in which the teacher reinforces these structures. The elements of the framework include (Johnson 1995: 9):

- forms of teachers' control of classroom communication - shaped mostly by their professional and practical knowledge;

- students' perceptions of these patterns - norms and expectations based on their previous learning experience, including preconceived notions of "appropriate" classroom communication;

- students' use of the target language;

- the extent to which the existing patterns of communication create opportunities for students to use the target language for classroom learning.

Johnson (1995: 100) postulates that, in order to be effective, classroom interaction must fulfill a number of conditions. First of all, it has to ensure the optimal conditions for target language learning and use, open up a space for both meaning-focused and form-focused language practice, and give students opportunities to use planned and unplanned discourse within authentic contexts. Secondly, it should enable learners to initiate interaction, control the topic and engage in meaning-focused discussion. Finally, classroom interaction is supposed to challenge students to operate beyond their current level of language proficiency by participation in the negotiation of meaning and performing different language functions. 
Leo van Lier (1996: 172) claims that classroom communication does not have to imitate closely the patterns typical of a casual, spontaneous conversation, as classroom interaction is a special kind of discourse constructed collectively by the teacher and students in which the focus of interaction may shift from the pedagogic to the natural mode at any moment. The specific property of classroom discourse referred to as contingency is central to van Lier's model, and may be interpreted as a kind of departure from the script of the lesson in response to the current circumstances of the ongoing communication in the classroom. As van Lier (2001: 99) puts it "when talk is contingent, utterances are constructed on the spot, rather than planned in advance". In other words, contingent classroom discourse is improvised and not based on a script, and as such it reflects the interplay between dependency and uncertainty in interactions (Pawlak 2004: 35) in which learners act communicatively, being, at the same time, resourceful with the language when they need to respond or provide a solution.

Accordingly, van Lier (1996: 178) distinguishes the following types of pedagogic interaction which are characterized by increasing levels of contingency:

Table 2. Types of pedagogic interaction (van Lier 1996: 178)

\begin{tabular}{|l|l|}
\hline \multicolumn{1}{|c|}{ Type } & \multicolumn{1}{c|}{ Characteristics } \\
\hline Transmission & $\begin{array}{l}\text { the delivery of information from one person to another in a mon- } \\
\text { ologic format, }\end{array}$ \\
\hline $\begin{array}{l}\text { IRF (initia- } \\
\text { tion/response/feedback) } \\
\text { questioning }\end{array}$ & $\begin{array}{l}\text { the eliciting of information by means of questions and answers, } \\
\text { where all the questions are asked by the same person (the teacher) } \\
\text { and the answers are provided by the learners; the questioner in } \\
\text { fact determines the character of the discourse used in the classroom, }\end{array}$ \\
\hline Transaction & $\begin{array}{l}\text { the exchange of information goes in two ways; the character of } \\
\text { the discourse is thus determined by all participants, }\end{array}$ \\
\hline Transformation & $\begin{array}{l}\text { discourse is jointly managed by all the participants, and this } \\
\text { influences the character of the learning situation by the possibility } \\
\text { of changing roles, relationships, learning aims and procedures; } \\
\text { meaning and events are co-constructed by all the contributors. }\end{array}$ \\
\hline
\end{tabular}

Hall and Verplaetse (2000) employ a sociolinguistic perspective and view language classrooms as discourse communities in which interaction is intended to foster students' language development. They interpret interactive processes in the classroom not as strictly individual or similar across learners and circumstances, but as a form of collaborative social enterprise connected with learners' regular participation in classroom activities. By means of social interactions "teachers and students work together to create the intellectual and practical activities that shape both the form and the content of 
the target language as well as the processes and outcomes of individual development" (Hall and Verplaetse 2000: 10).

Gil (2002) treats foreign language classroom discourse as consisting of two complementary modes, the pedagogical mode and the natural one, with a considerable amount of mingling and overlapping between the two. In her view it is a collectively built dynamic discourse type that aims at providing means for fostering language development. Bearing in mind the fact that classroom interactions occur in an institutional setting which equips the teacher with the most talking rights, Gil (2002: 277) postulates that more symmetrical relationships should be established by reducing the distance between the teacher and students and, consequently, giving students more talking rights.

Similarly, Garton (2002) points to the importance of learner initiative in the classroom and defines it as "an attempt to direct the interaction in a way that corresponds more closely to the interest and needs of the learners" (Garton 2002: 48). In order to achieve this aim, two conditions referring to learners' turns must be fulfilled. First, the learner's turn has to be selfselected (it cannot constitute a direct response to teacher's questions) and secondly, the learner's turn should gain the "main floor". These conditions indicate clearly that the effective promoting of learner initiative in interaction requires departing from teacher-fronted interaction patterns and involves changing the traditional roles in the classroom. In practical terms, it means giving learners space and time (Garton 2002: 52) by creating opportunities for their active participation in learning and allowing for more variability in interaction formats.

Seedhouse (2004) treats classroom discourse as an example of institutional interaction with its distinguishing "fingerprint", and claims that, regardless of the pedagogical framework of teaching or the approach adopted, the core institutional goal is always the same, that is "the teacher will teach the learners the L2". This situation affects the way in which classroom interaction is maintained and accomplished, and allows for identifying three interactional properties which derive from the core goal and shape classroom discourse (Seedhouse 2004):

- language functions as both the vehicle and the object of instruction,

- there is a reflexive evolving relationship between pedagogy and interaction - any variation in the pedagogical focus entails transformations in the organization of interaction,

- the forms and patterns of interaction produced by learners are potentially subject to evaluation.

Seedhouse (2004) considers the above properties as universal and applicable to all kinds of L2 classroom interaction, and designs a corresponding structural model. Thus, his analytical methodology for classroom discourse 
analysis, based on a conversation analysis approach, emerges directly from the structure of interaction and aims at determining the relationships between interaction and learning.

\section{PROBLEMS OF AUTHENTICITY}

As Majer (2003: 218) points out, classroom communication is often regarded by researchers as a somewhat unique type of interaction due to the fact that, although it possesses numerous universal characteristics, it is also marked by a number of features which are not found outside formal learning environments. The below table illustrates the differences between pedagogic and naturalistic L2 discourse, with the important reservation that the presented characteristics should be treated as opposite ends of continua and not as mutually exclusive terms (Majer 2003: 219):

Table 3. Fundamental differences between naturalistic and pedagogic L2 discourse (Majer 2003: 220)

\begin{tabular}{|l|l|l|}
\hline \multicolumn{1}{|c|}{ Characteristic } & \multicolumn{1}{|c|}{ Naturalistic 12 discourse } & \multicolumn{1}{|c|}{ Pedagogic 12 discourse } \\
\hline Goal & non-instructional & instructional \\
Function & social interaction & class management \\
Focus & meaning & form \\
Language & authentic & pre-planned \\
Use & communicative & pseudo-communicative \\
Structure & non-hierarchical & hierarchical \\
Style/register & informal & formal \\
Power relations & equalised & unequal \\
Directionality & two-way & one-way \\
Learner role & speaker & talker \\
Talk & symmetrical & asymmetrical \\
Pattern & information exchange & IRF/display questions \\
Input & teacher talk/peer talk \\
Metatalk & frequently used \\
Output opportunities & absent & limited \\
Switching to l1 & ample & frequent \\
Negotiation of meaning & none & frequent \\
Feedback & repair & error correction \\
\hline
\end{tabular}

In light of the above distinction it is not surprising that one of the most frequently recurring themes in the discussion on classroom discourse is the question of its authenticity, that is the extent to which it should reflect or does reflect naturalistic L2 discourse or natural communication in informal settings. Rivers (1993) defines authentic messages as those containing infor- 
mation which is of interest to both the speaker and the listener. Authentic communication is not confined to expressing one's own ideas but also involves comprehending the ideas of others. Seen in this light, interaction serves as a common ground where the participants work out an interpretation of meaning through communication. This interpretation is echoed in Ellis's view (Ellis 1999), according to which classroom language can be experienced as authentic communication, but this situation may take place on condition that the participants of interactive activities in the classroom share discourse rights.

Widdowson (1998) interprets authenticity as a social construct and relates it to the learning activity rather than to the origin of material or language used in classroom interactions. Importantly, Widdowson (1998) claims that inauthentic language-using behaviour may well be effective language-learning behaviour. In his view the term authenticity refers, then, to the process of authentication which arises from involvement with the learning task. Similarly, van Lier (1996: 128) states that "authenticity is the result of acts of authentication, by students and their teacher, of the learning process and the language used in it".

Wilczyńska (2002) puts forward a broader concept of authenticity, corresponding to her model of individual communicative competence. Thus, communicative authenticity is defined as a form of personal involvement in interaction which reflects a learner's personality, capabilities, goals and aspirations. It is manifested in the individual communicative style and implies negotiating interlocutors' objectives and statuses in interaction. By referring to the notion of self-regulation as understood in the Vygotskyan perspective, Wilczyńska (2002) underlines that authentic communicative actions activate the three main intellectual functions essential to developing foreign language competence, that is thinking, speaking and learning. Such an interpretation of communicative authenticity largely expands the scope of the term, incorporating the individual dimension and stressing the role of selfregulative mechanisms in shaping the learner's communicative abilities.

The conclusion which may be drawn from the above discussion is that authentic or "contingent" classroom communication needs space which allows for personalizing the content of learning and communicating, and creates opportunities for expressing individually relevant and meaningful messages or ideas. Needless to say, it is more likely to be found in learnercentered classrooms characterized by symmetrical relationships between the participants of the learning process and, consequently, a well-balanced distribution of talking rights as opposed to teacher-fronted classroom formats. The latter pattern, dominant in traditional teacher-controlled classrooms, is frequently thought of as a form of institutional talk and marked by a number 
of easily noticeable, typical characteristics such as (Garton 2002: 47): clearly defined pedagogic goals, entering interaction for specific learning purposes, taking on the roles of "an instructor" and "the instructed", following basic rules of participation (one person speaks at a time or multiple speakers express similar ideas) and very limited or non-existent learner initiative.

Although there is a growing tendency in modern language classrooms to shift towards learner-oriented modes of interaction and abandon the above format, some (or all) of the above mentioned features are in fact present, to a greater or lesser degree, in most instructional learning environments. This situation contributes to the fact that classroom interaction is sometimes stereotypically viewed as an example of artificial or inauthentic discourse which bears little or no resemblance to natural communication and, therefore, is not particularly helpful in preparing learners for unassisted real-life language use.

As a consequence and, in a way, in response to the practical needs of the field, much of the research on classroom communication still focuses on the differences between pedagogic and natural or naturalistic discourse, and aims mainly at indicating the deficiencies of classroom interaction. In other words, the focus of the research is frequently rather on what classroom discourse should be, and not on what it actually is (Gil 2002: 275). This approach is criticized by van Lier (1996) who claims that too much emphasis is given to identifying the gaps between natural and pedagogic communication. Gil (2002: 274) finds it inadequate as it fails to capture the specific dynamics of classroom discourse and tends to attribute a positive value only to interactions which resemble natural conversation, excluding the inherent pedagogical aspect. Similarly, Majer (2003: 14) underlines the fact that although classroom communication may differ from naturalistic discourse in many ways, it should not be seen as "deviant" or "distorted" since, in fact, it is authentic in instructional learning settings and constitutes a discourse domain in its own right.

It has to be pointed out, however, that the research which aims at identifying the differences between natural communication and classroom discourse may serve, or does serve, quite an important pedagogic and practical aim, namely narrowing the gap between genuine interactions and classroom communication and working out efficient ways of increasing the quality and quantity of learners' language production. The above issue also lies at the root of much of the research on classroom discourse carried out in the Polish educational context in which the asymmetry of relationship between teacher and learners and the resultant unequal distribution of rights or students' unwillingness to participate in classroom interaction are commonly observed. 
The main focus of the study conducted by Pawlak (2004) was the comparison of interactive processes promoted by Polish and American teachers and the evaluation of the effectiveness of a number of process variables (turn-taking, discourse structure, interaction types, teachers' questions, students' communication strategies, effectiveness of group work, use of the learners' first language, repair techniques) in developing learners' communicative competence in the target language. Interestingly, Pawlak (2004: 81) states that "the teachers' linguistic background and teaching experience do not necessarily affect various aspects of classroom discourse to the same extent" (Pawlak 2004: 81). In conclusion Pawlak (2004: 81) claims that factors such as the format of the lesson, teaching style or students' involvement may in fact influence the character of classroom interaction more than the presence or absence of a native speaker with limited teaching experience.

In the same study, an analysis of different aspects of classroom communication revealed that an attempt at "replicating the characteristics of general conversation in the foreign language classroom does not necessarily promote language development and, in some cases, it can even hinder rather than foster that process" (Pawlak 2004: 103). This significant observation is explained in terms of the availability of the shared mother tongue and learners' perception of the classroom as an artificial environment. Moreover, too much insistence on following the patterns typical of casual conversation may reduce students' speaking opportunities, particularly in the case of less proficient or less confident learners, and result in excessive use of the native language when communication problems are encountered. As Pawlak (2004: 103) concludes, a way out of the predicament may be an attempt to combine meaning-focus and form-focused instruction. Such an approach is likely to provide the students with communicative skills and ensures the sufficient amount of explicit instruction or corrective feedback necessary for language development.

The asymmetry of communication in the language classroom is also underlined by Piotrowski (2011) who interprets classroom discourse as a kind of exolingual communication marked by its plurifocalisation, that is concentrating interlocutors' attention on both the meaning and form of utterances but also, importantly, on the process of performing a specific task (Piotrowski 2011: 18).

An exclusive focus on meaning is not easily achievable in classroom conditions, due to the fact that learners' language production is often a form of realization of a specific task and it is subject to some form of evaluation. As a result, most utterances are in fact messages with double focus (form and meaning). On the other hand, focus on form in naturalistic settings 
serves a different purpose, namely it reflects the intention of overcoming a communicative problem. In the classroom, however, a potential "communicative problem is pushed to the background" (Piotrowski 2011: 219) and focus on form results rather from the type of evaluation, self-assessment or corrective feedback from the teacher. Last but not least, the third kind of focus may be observed in classroom interactions, that is the focus on the process of task performance which may be expressed by a learner's own verbalized reflection (metalinguistic comment in the native language) on the task being performed (Piotrowski 2011: 223). Unlike natural communication, classroom discourse is then characterized by the dominance of focus on form and the task performance process and, consequently, meaning-oriented utterances, which constitute most of authentic natural communication, are not common occurrences (Piotrowski 2011: 226). In order to narrow this gap, Piotrowski (2011) suggests reducing the use of the first language to the minimum, since its excessive use functions as a barrier which makes learners communicate below their actual level of competence and does not allow for exploiting the potential of metacommunication in the target language.

Several other aspects of classroom discourse have recently been the object of interest among Polish researchers. The research projects mentioned below focus on various elements or dimensions of classroom discourse, however they all, directly or indirectly, contribute to the discussion on the authenticity of communication in different instructional environments in the reality of Polish institutional education:

Table 4. Selected research on classroom discourse in Poland (2008-2011)

\begin{tabular}{|l|l|}
\hline \multicolumn{1}{|c|}{ Research areas } & \multicolumn{1}{|c|}{ References } \\
\hline Sociocultural aspects of code-switching in L2 classroom discourse & (Majer 2011) \\
\hline $\begin{array}{l}\text { Modeling classroom communication in instructed acquisition of } \\
\text { speaking }\end{array}$ & (Pawlak 2011) \\
\hline $\begin{array}{l}\text { Speaking in English for academic purposes in the light of sociocul- } \\
\text { tural theory }\end{array}$ & (Niżegorodcew 2011) \\
\hline Representations, strategies and skill acquisition in L2 interactions & (Wojciechowska 2010) \\
\hline Discursive strategies in foreign language academic interactions & (Orchowska 2010) \\
\hline $\begin{array}{l}\text { The role of the teacher in shaping interactive processes in the class- } \\
\text { room }\end{array}$ & (Pawlak 2009) \\
\hline Negotiation of form in foreign-language classroom discourse & (Majer 2008) \\
\hline $\begin{array}{l}\text { The validity and effectiveness of the research on the development } \\
\text { of individual communicative competence in L2 interactions }\end{array}$ & (Mosorka, \\
Wojciechowska 2008) \\
\hline $\begin{array}{l}\text { Teachers' use of interaction patterns in the foreign language class- } \\
\text { room and its influence on learners' oral fluency }\end{array}$ & (Łęska 2008) \\
\hline
\end{tabular}




\section{FRAMEWORKS FOR CLASSROOM DISCOURSE ANALYSIS}

Different traditions in classroom discourse analysis stem from a variety of theoretical orientations which seem to share a common conviction that learning how to communicate in a foreign language happens by means of interactions, in particular interactions between teachers and learners as opposed to interactions occurring between students. The most pertinent analytic frameworks: interaction analysis, discourse analysis and conversational analysis all have their contributions as well as limitations but, taken together, they definitely help in a better understanding of the complexities involved in investigating language classroom discourse.

An interaction analysis approach, rooted in behavioral psychology, is often viewed as an objective method of analyzing classroom discourse (by means of observation and specific coding systems) as it is capable of establishing reliable classroom profiles through quantitative statistical procedures which are generalizable (Lee 2011: 11). Among several coding systems developed within the approach, Flanders' FIAC (Interaction Analysis Categories), Moskowitz's FLint (Foreign Language Interaction), Fanselow's FOCUS (Foci for Observing Communications Used in Settings) and COLT (Communicative Orientation of Language Teaching) are probably the most wellknown and most frequently used by researchers.

Although it cannot be denied that the IA approach has contributed to an overall understanding of classroom discourse, it is frequently criticized for failing to give a complete picture of classroom communication and focusing only on what is actually observable or measurable. In consequence, some potentially significant aspects of interaction may be ignored in the research process, due to the fact that the patterns being observed "have to be matched to a priori categories that the schemes have delineated" (Lee 2011: 12) and linguistic behaviours which do not fall into the fixed formula (such as overlaps, interruptions or false starts) are not examined. Another criticism against the interaction analysis approach points to the fact that it assumes that classroom discourse proceeds in an orderly, sequential manner, which is not necessarily the case. The strongest argument against the IA approach is, however, its tendency to oversimplify the research context and employ a fixed set of criteria for evaluating all kinds of classroom interactions, therefore giving a one-sided and rather incomplete picture of what in fact occurs in the language classroom (Seedhouse 2004).

Discourse analysis approaches follow the principles of structuralfunctional linguistics and explore the structural patterns and functional aims of classroom communication. The model adopted in the approach reflects a discourse hierarchy and consists of several levels, each unit being com- 
posed of elements from the previous level: lesson $>$ transaction $>$ exchange $>$ move $>$ act (Lee 2011: 14). Particular attention is given to the exchange level, at which the following interactional patterns are observable: question and answer sequences (IRF structure), students' responding to teachers instructions and students listening to the teacher giving directions. Different combinations of these exchanges are referred to as transactions, however, what is considered to be the most distinguishing feature of classroom discourse is the IRF structure, a form of triadic dialogue most commonly observed in traditional teacher-fronted language classrooms. For that reason, the DA framework and the rigid exchange model are criticized for being inadequate in examining modern learner-centered classrooms where discourse practices are based more on partnership and equal distribution of rights, and are generally marked by an attempt to create more symmetrical relations between teachers and students. Additionally, as many researchers claim, this analytic framework does not quite embrace the unpredictable nature and dynamics of classroom interaction and fails to capture the identities of interaction participants, contextual backgrounds of communication and sociocultural factors (Lee 2011).

The above gap is addressed by the conversation analysis approach, rooted in the ethnomethodological tradition, originally focusing on natural communication and later employed in classroom discourse research (Seedhouse 2004). The approach is based on the assumption that the social contexts of communication are fluid and they are dynamically created in interactions, which is manifested through the interlocutors' use of language, in particular through the sequential organization of interaction (Heritage 2004). The management of turn-taking, openings and closures, sequencing of acts and adjacency pairs is given a special emphasis within the framework. Importantly, the context is viewed as both a projection and a product of the interlocutors' actions (Heritage 2004), and interaction is interpreted in terms of goal-orientation towards an objective connected with the institutional talk (Lee 2011: 17).

The main difference between the interaction analysis or discourse analysis approaches and conversation analysis lies in its rejection of predetermined categories and the claim that interaction patterns should be identified and categorized on the basis of the data gathered in a particular research context. This lack of preconceived ideas and the focus on the sequential structure of interaction are considered to be the greatest strengths of the approach. Yet they are also frequently regarded as its shortcomings, due to the random, impressionistic or sometimes chaotic character of the data collected. Moreover, as it offers rather a localized small-scale analysis of interaction, a conversation analysis approach makes no claim to extending find- 
ings to other contexts and, in consequence, is of rather limited value in defining longitudinal effects of particular interactional formats on learning.

Irrespective of the methodological choices, any research project which aims to provide valid and practically relevant findings requires a careful selection of an analytic framework which should take into account the research objectives and researchers' capabilities in a given context. In light of the complexity of classroom discourse as a research area - if only to mention the time-consuming process of data collection and analysis, the technical and ethical problems involved or the observer's paradox (Majer 2009: 102), it seems that the appropriate choice of data collection methods, the technique of transcription and ways of interpreting data are of particular importance, both in larger-scale classroom research as well as in small-scale action research projects intended to improve the existing teaching and interactional practices in a concrete educational setting.

\section{CONCLUDING REMARKS}

To sum up, it seems that what determines the authenticity of classroom communication to the greatest extent is, then, the teacher's and learners' ability to establish communicative patterns and rituals which foster authentic target language interaction in a given classroom. Any attempts at copying or imitating natural, informal interaction seem unrealistic, as the classroom creates its own dynamic and unique environment governed by rules, goals and mechanisms different from those prevailing in natural settings. As Widdowson (1998: 711) claims:

The authenticity or reality of language use in its normal pragmatic functioning depends on its being localized within a particular discourse community. Listeners can only authenticate it as discourse if they are insiders. But learners are outsiders, by definition, not members of user communities. So the language that is authentic for native speaker users cannot possibly be authentic for learners.

Accordingly, the authenticity of classroom interaction should therefore be understood and explored rather within its specific context (both in its social and individual dimension) than by following the universal standards of natural or naturalistic discourse. It cannot be denied that most foreign language learning does occur in language classrooms which, in this sense, function as authentic real-life environments for foreign language learning and use. Obviously, the character of these interactions reflects not only learners' linguistic repertoires, but also, to a great extent, the nature of the relationship between the teacher and learners in a particular classroom and 
individual learners' personalities, experiences or goals. Undoubtedly, learner-oriented classrooms create more opportunities for learners to engage in meaningful and individually authentic discourse by opening up more space for communicating social and personal content. Yet, the relatively strong position of the traditional, teacher-fronted model of communication and the amount of teacher-controlled interaction cannot be ignored in classroombased research.

\section{REFERENCES}

Allwright, D., 1988. Observation in the Language Classroom. London: Longman.

Amidon, E.J., Hough, J.B. (eds). 1967. Interaction Analysis. Theory, Research and Application. Reading: Addison-Wesley.

Barnes, D., Britton, J., Rosen, H. (eds). 1969. Language, the Learner and the School. Harmondsworth: Penguin.

Bellack, A.A., Kliebard, H.M., Hyman, R.T., Smith Jr., F.L. 1966. The Language of the Classroom. Final Report, USOE Cooperative Research Project, No. 2023. New York: Teachers College Press, Columbia University.

Bernstein, B., 1990. Class, Codes and Control vol. 4: The Structure of Pedagogic Discourse. London: Routledge.

Chaudron, C., 1988. Second Language Classrooms: Research on Teaching and Learning. Cambridge: Cambridge University Press.

Cullen, R., 1998. Teacher Talk and the Classroom Context. In: ELT Journal, 53, 179-187.

Ellis, R., 1994. The Study of Second Language Acquisition. Oxford: Oxford University Press.

Ellis, R., 1999. Learning a Second Language through Interaction. Amsterdam: John Benjamins.

Flanders, N.A., 1970. Analyzing Teaching Behavior. Reading: Addison-Wesley.

Garton, S., 2002. Learner Initiative in the Language Classroom. In: ELT Journal, 56/3, 47-56.

Gil, G., 2002. Two Complementary Modes of Foreign Language Classroom Interaction. In: ELT Journal, 56/3, 273-279.

Hall, J.K., Verplaetse, L.S., 2000. The Development of Second and Foreign Language Learning through Classroom Interaction. In: Hall, J.K., Verplaetse, L.S. (eds). Second and Foreign Language Learning through Classroom Interaction. Mahwah, New Jersey: Lawrence Erlbaum Associates, 1-16.

Hatch, E.M., 1992. Discourse and Language Education. Cambridge: Cambridge University Press.

Heritage, J., 2004. Conversation Analysis and Institutional Talk: Analyzing Data. In: Silverman, D. (ed.). Qualitative Research: Theory, Method and Practice. London: Sage, 222-245.

Johnson, K.E., 1995. Understanding Communication in Second Language Classrooms. Cambridge: Cambridge University Press.

Larsen-Freeman, D., 1998. Doing Teacher Research: from Inquiry to Understanding. Boston: Heinle and Heinle.

Lee, J., 2011. A Genre Analysis of Second Language Classroom Discourse: Exploring the Rhetorical, Linguistic, and Contextual Dimensions of Language Lessons. In: Applied Linguistics and English as a Second Language Dissertations. http://digitalarchive.gsu.edu/alesl_diss/20. (date of access: 11. 12. 2012)

van Lier, L., 1996. Interaction in the Language Curriculum: Awareness, Autonomy, and Authenticity. London: Longman. 
van Lier, L., 2001. Constraints and Resources in Classroom Talk: Issues of Equality and Symmetry. In: Candlin, C., Mercer, N. (eds). English Language Teaching in its Social Context. London: Routledge, 90-107.

Long, M.H., Richards, J.C. (eds). 1987. Methodology in TESOL. A Book of Readings. Boston: Heinle and Heinle.

Lynch, T., 1996. Communication in the Language Classroom. Oxford: Oxford University Press.

Łęska, K., 2008. Teachers' Use of Interaction Patterns in a Foreign Language Classroom and Gains in Students' Oral Fluency. Częstochowa: Wydawnictwo Wyższej Szkoły Lingwistycznej.

Majer, J., 1998. Analysis of Classroom Communication: Implications for Teacher Training. In: Lewandowska-Tomaszczyk, B. (ed.). Perspectives on Foreign Language Teaching. Piotrków Trybunalski: Kielce Pedagogical University Affiliated College at Piotrków Trybunalski Press, 8-25.

Majer, J., 2003. Interactive Discourse in the Foreign Language Classroom. Łódź: Wydawnictwo Uniwersytetu Łódzkiego.

Majer, J., 2008. Negotiation of Form in Foreign-Language Classroom Discourse. In: Pawlak, M. (ed.). Investigating English Learning and Teaching. Poznań-Kalisz: Wydawnictwo Wydziału Pedagogiczno-Artystycznego UAM w Kaliszu, 79-94.

Majer, J., 2009. Analiza dyskursu na lekcji języka obcego. In: Neofilolog, 32, 99-114.

Majer, J., 2011. Talking the Same Language: Sociocultural Aspects of Code-Switching in L2 Classroom Discourse. In: Pawlak, M., Waniek-Klimczak, E., Majer, J. (eds). Speaking and Instructed Foreign Language Acquisition. Bristol: Multilingual Matters, 66-83.

Mehan, H., 1979. Learning Lessons: Social Organization in the Classroom. Cambridge: Cambridge University Press.

Moskowitz, G., 1971. Interaction Analysis: a New Modern Language for Supervisors. In: Foreign Language Annals, 5, 211-221.

Mosorka, E., Wojciechowska, B., 2008. Rzetelność i efektywność badań rozwoju osobistej kompetencji komunikacyjnej w ustnych interakcjach obcojęzycznych. In: Neofilolog, 31, 41-49.

Niżegorodcew, A., 1991. Dyskurs interakcyjny a kompetencja komunikacyjna w języku obcym. Kraków: UJ.

Niżegorodcew, A., 1993. The Structure of Foreign Language Discourse and the Use of Communication Strategies by Low Proficiency Foreign Language Learners. In: Kettemann, B., Wieden, W. (eds). Current Issues in European Second Language Acquisition Research. Tubingen: Gunter Narr, 349-357.

Niżegorodcew, A., 2011. Speaking in English for Academic Purposes in the Light of Lingua Franca English and Sociocultural Theory. In: Pawlak, M., Waniek-Klimczak, E., Majer, J. (eds). Speaking and Instructed Foreign Language Acquisition. Bristol: Multilingual Matters, 84-95.

Nunan, D., 1989. Understanding Language Classrooms. A Guide for Teacher-Initiated Action. New York: Prentice Hall.

Nunn, R., 1999. The Purpose of Language Teachers' Questions. In: IRAL, 37, $23-42$.

Orchowska, I., 2010. Wpływ strategii dyskursywnych na realizację celów uczeniowych i heurystycznych w sytuacji konsultacji seminaryjnych. In: Pawlak, M., Waniek-Klimczak, E. (eds). Mówienie w języku obcym - sukcesy i porażki uczenia się i nauczania. Poznań-KaliszKonin: Wydawnictwo Wydziału Pedagogiczno-Artystycznego UAM w Kaliszu i Wydawnictwo PWSZ w Koninie, 313-327.

Patil, P.B., 1994. Strategies of Teacher Talk. In: IRAL, 32, 154-165.

Pawlak, M., 2004. Describing and Researching Interactive Processes in the Foreign Language Classroom. Konin: Wydawnictwo Państwowej Wyższej Szkoły Zawodowej w Koninie. 
Pawlak, M. 2009. Rola nauczyciela w kształtowaniu procesów interakcyjnych w klasie językowej. In: Pawlak, M., Mystkowska-Wiertelak, A., Pietrzykowska, A. (eds). Nauczyciel języków obcych dziś i jutro. Poznań-Kalisz: Wydawnictwo Wydziału Pedagogiczno-Artystycznego UAM w Kaliszu i Wydawnictwo UAM w Poznaniu, 311-337.

Pawlak, M., 2011. Instructed Acquisition of Speaking: Reconciling Theory and Practice. In: Pawlak, M., Waniek-Klimczak, E., Majer, J. (eds). Speaking and Instructed Foreign Language Acquisition. Bristol: Multilingual Matters, 3-23.

Pica, T., 1987. Second Language Acquisition, Social Interaction, and the Classroom. In: Applied Linguistics, 8, 3-21.

Pica, T., 1994. Questions from the Language Classroom: Research Perspectives. In: TESOL Quarterly, 28, 49-79.

Piotrowski, S., 2011. On the Authenticity of Communication in the Foreign Language Classroom. In: Pawlak, M., Waniek-Klimczak, E., Majer, J. (eds). Speaking and Instructed Foreign Language Acquisition. Bristol: Multilingual Matters, 215-229.

Politzer, R.L., 1980. Requesting in Elementary School Classrooms. In: TESOL Quarterly, 14, 165-174.

Richards, J.C., Lockhart, C. 1994. Reflective Teaching in Second Language Classrooms. Cambridge: Cambridge University Press.

Riley, P. (ed.). 1985. Discourse and Learning. London: Longman.

Rivers, W., 1993. Interactive Language Teaching. Cambridge: Cambridge University Press.

Seedhouse, P., 2004. The Interactional Architecture of the Language Classroom: A Conversation Analysis Perspective. Malden: Blackwell.

Seliger, H.W., 1977. Does Practice Make Perfect? A Study of Interaction Patterns and L2 Competence. In: Language Learning, 27, 263-278.

Sinclair, J., Coulthard, M., 1975. Towards an Analysis of Discourse: The English Used by Teachers and Pupils. London: Oxford University Press.

Thompson, G., 1997. Training Teachers to Ask Questions. In: ELT Journal, 51, 99-105.

Wallace, M.J., 1998. Action Research for Language Teachers. Cambridge: Cambridge University Press.

Widdowson, H.G., 1998. Context, Community and Authentic Language. In: TESOL Quarterly, $32(4), 705-716$.

Wilczyńska, W. 2002. Wprowadzenie: cele i założenia projektu PA. In: Wilczyńska, W. (ed.). Autonomizacja w dydaktyce języków obcych. Doskonalenie się w komunikacji ustnej. Poznań: Wydawnictwo Naukowe UAM, 15-27.

Wojciechowska, B., 2010. Autentyczność w obcojęzycznych interakcjach komunikacyjnych: reprezentacje, strategie, nabywanie umiejętności. In: Pawlak, M., Waniek-Klimczak, E. (eds). Mówienie w języku obcym - sukcesy i porażki uczenia się i nauczania. Poznań-KaliszKonin: Wydawnictwo Wydziału Pedagogiczno-Artystycznego UAM w Kaliszu i Wydawnictwo PWSZ w Koninie, 301-312.

Yule, G., Tarone, E., 1997. Investigating Communication Strategies in L2 Reference: Pros and Cons. In: Kasper, G., Kellerman, E. (eds). Communication Strategies. Psycholinguistic and Sociolinguistic Perspectives. London: Longman, 17-30. 
